\title{
Silence Sits in Places
}

\section{Chronic Illness and Memory in Northern Morocco}

\section{Federico Reginato}

\begin{abstract}
Aвstract: Having become interested in the uprising of the Hirak movement and its denouncement of a 'cancer epidemic' in the Moroccan Rif, I ended up having what appeared to be a shattered experience, one broken by refusals to speak, miscommunication and bureaucratic barriers. Upon returning home, the very same silence that had surrounded my fieldwork then emerged as a resourceful tool with which to make sense of an opaque history. In this article, I will therefore consider silence as a social object that we encounter during fieldwork, as a positional issue and as an epistemological space. In this sense, engaging with what appears to be at the margin of everyday speech requires consideration of silence as something that is made powerful precisely by its being left unsaid.
\end{abstract}

KeYwords: cancer, Hirak, Morocco, Rif, silence, transitional justice, Years of Lead

The returns to the subject still map out ... dangerous anthropological terrain - raucous terrae incognitae and landscapes of explosions, noise, alienating silences, disconnects and dissociations, fears, terror, machineries, pleasure principles, illusion, fantasies, displacements and secondary revisions, mixed with reason, rationalisations, and [the] paralogical - all of which have powerful socio-political dimensions and effects.

(Micheal M.J. Fischer, in Biehl et al. 2007: 442)

As junior and young medical anthropologists, writing about subjectivities in the twenty-first century seems indeed a difficult task: we move in a space and time quite different from those associated with the debates over the rationality of 'non-biomedical' etiological paradigms and social constructions of diseases and illness narratives, however critical these continue to be. We are increasingly confronted with worlds shaped by the intertwining of global governmental politics and local 'assemblages' (Collier and Ong 2005), of transversal economic disparities and specific forms through which inequalities are produced, distributed and objectified. We increasingly work in settings of violence or post-conflict settings, engaging issues of humanitarian interventions, undocumented populations, and new forms and categories of citizenship and technologies that escape clinical settings. All this seems to reactualise old challenges of balance between the narration of subjective trajectories and pervasive structures, asking us to relentlessly confront our writing and our approach in the field: how can we harmonise the contribution of critical theory with concrete desires and expectations of individuals without reducing the former to an inadequate formulation and the latter to the mere prey of invisible forces?

This interrogative becomes crucially compelling in fieldwork where the study of health politics and experiences of suffering often results in a misunderstanding of the role and the aims of the research. In these contexts, the idea of doing 'research for research's sake' reveals the anthropological enquiry first and foremost as an intrusion into others' issues and lives, bringing us immediately to confront another disciplinary ghost. As Linda Tuhiwai Smith states in her book Decolonizing Methodologies, 'the word itself, "research", is probably one of the dirtiest words in the indigenous world's vocabulary. When mentioned in many indigenous contexts, it stirs up 
the silence, it conjures up bad memories, it raises a smile that is knowing and distrustful' (1999: 1). How, then, can we address the intricacy of colonialism, inequality, violence and conflict inhabiting both the post-colonial contexts with which we confront and the history of our discipline?

\section{In the Field Alone}

During my first foray into the field in Morocco, where I conducted work on the relations between colonial history, health politics and social representations in the Rif, ${ }^{1}$ the two above-mentioned questions came into being, and they were embodied in the discourses with my interlocutors. Too many encounters ended with a kind request to change the subject or to not report the story that I had heard. Some ended with a sense of mystification and incomprehension at my research interest - and some even ended in my interlocutor taking offence at the apparent 'nonsense' of my project. And so this was often the case with the dialogues I had with local authorities, who were interested in monitoring my work in a time of social conflict and historical change, and with the dialogues with patients, relatives, activists and local political association members, who were more concerned about finding concrete solutions to their problems then with helping me with my research or with using it as a tool with which to legitimise their political discourses.

Moving across bureaucratic restrictions and ordinary refusals, denials of permissions and resentful silences, requests to fill out forms and to submit the work to local authorities, I experienced the difficulty inherent in constantly having to reconcile my activity and presence as a researcher with the objectives of my interlocutors.

Mediating between and balancing different situations, desires and scopes is indeed what anthropology does: the constant handling and confronting of unexpected requests, situations and interpretations that produce anthropological work as a co-construction that one creates with the encounters, friends, interlocutors and supervisors that one meets in the field. Anthropology is a collective gesture, and here resides part of its critical potential. Still, when confronting contemporary landscapes inhabited by haunting memories, conflicts and inequalities, this balancing cannot be reduced to fixed paradigms or to a few critical assumptions.

In what follows, I would like to share a brief reflection about how these topics had taken shape by the end of my fieldwork. In doing so, I will frame the role of silence as a peculiar fil rouge that ran throughout the course of my fieldwork, posing both practical and ethical challenges.

First, I will consider silence in its concrete dimension: as something that we hear, that we are asked to keep or even to listen to, that we can see and that reveals its presence precisely by its 'being left unsaid' (Good 2012: 534) and unseen. By exploring some ethnographic and historical shards of my fieldwork in the Rif, I will try to offer some pieces of the mosaic of political censoring, social stigmatisation and historical burden that surround life in the region. Here, the use of sociological discourses 'against' silence and the use of individual practices 'favouring' silence can be looked at like a set of 'tactics' (De Certeau 2006) that are difficult to reduce either to subaltern strategies or to innovative cultural solutions.

This last point will bring me to the second section of article, in which I will briefly explore silence in its ethical dimensions. How does one confront and/or speak about suffering when silence is both a context and a solution? In this last section, I will expose some unstructured, fragmented experiences from my time spent in the oncology centre of Al Hoceima.

\section{Pieces}

\section{One, Many, Hundreds of Rifs}

It is 13 May 2017; Rabat is already coated in hot, still air. The secretary of the Health Minister is smiling at me, my introductory letter still lying on the table in the Minister's office:

Rif? What do you mean, what is this Rif? Rif is not a region sir: it is a mountain chain that crosses regions of Tangier-Tetouan-Al Hoceima, l'Oriental, and FezMeknes. It is a mountain chain. You see . . . when I hear talking about the Rif, I know this means two things: a political interest in Berbers and a historical interest in national facts. This letter tells me that you want to make a research in the Rif, hence in political and historical issues. But you see, Sir Reginato-and here the secretary is drawing the number six on a small piece of paper, offering it to my sight-we can look at the Rif from the point of view of Hirak - now smiling he turns the paper, making the six into a nine-or from others points of view. Nowadays the Rif doesn't exist anymore, you understand what I mean? It's simply a mountain chain and to keep talking about it helps only spreading folkloristic descriptions, victim mentalities, potentially dangerous behaviours.

(Mrs. Amine, Rabat, 13 May 2017)² 
At that time, the Rif was very much discussed indeed. A social and political protest movement, the Hirak al Shaabi, had originated seven months before in the cities of $\mathrm{Al}$ Hoceima and Imzouren situated in the central Rif, and since then it had been protesting about the poor economic, infrastructural and political situation in the region. The absence of the state and any development plans, infrastructural abandonment, economic misery, massive militarisation and administrative corruption were among the issues reported by the movement. By June 2017, the Hirak had assumed national proportions, and after the arrest of the symbolic leader of the movement, Nasser Zafzafi, supportive protests arose in the main urban centres of the region, Rabat and Casablanca.

As a Master's student in a local university of Rabat, I spoke with colleagues and professors about the political and media resonance of the protests. Friends who were born in the Rif had told me about tormented past relations between the region and the central authority: the strong militarisation of the area, which occurred in 1958, was claimed to still be active and ongoing, a trace of the repression of protestors and civilians during the so-called 'Years of Lead', the period of nationalisation during which many violent acts, incarcerations and military reprisals against dissidents and political opponents occurred. With the ascent to the throne of King Mohammed VI, the violent crimes that were perpetrated by his predecessor and kept as a astate secret were unsealed, leading to a process of 'reconciliation' that culminated with the institution of the Equity and Reconciliation Commission (ERC) or Instance Equité et Réconciliation (IER) and the re-emergence of social memories and witnesses once censored, the reappearance of a hushed national history (Nahass 2014).

This particular historical trajectory acquired additional significance during the summer of 2017, becoming the last demonstration of a complex legacy of rebellion still felt in the Rif. From the first descriptions of Berbers (a term etymologically derived from the word for 'barbarians') as fierce savages constantly at war, as depicted by the ancient Greek historian Herodotus, across the opposition between bled al Makhzen and bled al Siba, the governed and anarchic parts of the country described in the work of Ibn Khaldoun (in his Muqadimmah of 1377), to the history of anti-colonial revolt and then to the recent time of post-colonial Morocco (Ayache 1981; Montagne 1954; Rachik 1990), the Rif was described in media, political and sociological discourses as a characteristic - almost stereotypical - place of rebels. This portrayal reactivated a dualistic imaginary between centre and periphery, Arabs and Berbers, to whom colonial administrations and even recent anthropologists have also contributed (Gellner 1969; Gellner and Michaud 1972).

This deterministic description was in part the cause of renewed attention to the Hirak from international media and political associations, generating a public narrative around the 'historical' resistance of Rifans against occupying forces that had succeeded through history. At the same time, different members of the Moroccan Parliament, motivated by issues raised by the movement, started to accuse the state of failing to politically intervene in the region and improve its economic and infrastructural situation. In the national and international media, in the prevailing political discourse and in civil society meetings, Hirak was considered in opposed (but not contrasted) ways: as the result of years of abandonment and isolation in the region and as a dangerous artefact created by Algerians or by local elites, whose purpose was to create agitation in the Moroccan region to destabilise the Kingdom.

\section{Gas, Politics, Cancer: A Historical Etiology}

I started to become interested in researching the reason for some claims that appeared in the movement's discourses and slogans. Particularly, I became curious about the 'culturalist' rhetoric used by the Hirak, which appeared in the public arena about the singular emergency of a 'cancer epidemic': an epidemic they attributed to the usage of toxic gas by the Spanish Army between 1921 and 1926 during the years of the Protectorate.

The Hirak's slogans about a poisoned land and a historical epidemic that was never addressed revealed a completely obscured episode. In all the years of political and institutional reconciliation with the local population, as well as in the Parliamentary sessions or in the encounters and programmes to reconcile the national memory, the usage of gas during the 1920s was left undiscussed and unnamed. Even if some studies discovered the criminal use of yprite (mustard gas) in the Rif by exploring government archives and informal military letters (Balfour 2002), the usage of the toxic weapon was never acknowledged by the Spanish or the Moroccan governments or monarchies.

Also, the political programme of intervention for cancer prevention and detection and oncological care that started in 2011 in Morocco, while providing instruction for all the main and marginal areas, nevertheless left the Rif's situation completely to one side, centralising all the sanitary infrastructures in 
the area of Tangier, which is $300 \mathrm{~km}$ away from $\mathrm{Al}$ Hoceima. Finally, the lack of specialised and general public healthcare in the area corresponded to a general lack of epidemiological information: no data was produced on cancer incidence in a region that still accounts for 8 per cent of the national population (HCP 2014). Only a small oncological centre was present in Al Hoceima, a two-storey building isolated and situated next to the bus station. Around this centre, also, doubts arose in political and public discourses: it seemed that it had been built in 2015 for a King's concession but that since then it had remained closed.

While the region was institutionally abandoned, these issues emerged during public debates and during interviews with Hirak movement members, presenting the situation of Rifans as dire: they felt repressed, oppressed and abandoned. The social movement appeared in the media and in debates as an effective solution par le bas capable of giving voice to those who were 'unable to speak', like the subalterns of Antonio Gramsci (1977) and Gayatri Spivak (1988): as a response to the epidemiological absence of data, Rifan political associations and the Hirak movement mobilised 'circumstantial' knowledges (Ginzburg 1986) and 'tactics' (De Certeau 2006) by cross-referencing different sets of aetiological data from the paediatric hospital and from all the hospital centres in which the provenance of patients was indicated, and by presenting the results of the autonomous research conducted by association members, European historians and European anthropologists.

In this regard, I found incredibly rich and interesting what Mr. Raha, the president of the Assemblée Mondiale des Amazighs, told me during our first encounter:

The Hirak is the manifest presence of a cultural and historical difference that must be acknowledged. Tamazgha [the mythical North African reign of Berbers preceding the arrival of Arabs] has crossed the Roman Empire, the Arab invasion, and European colonialism, and it has been deprived of all its culture, its sanctuaries. Here I have the oncological data of the paediatric hospital of Rabat, where it is reported how most kids that contracted tumours came from the north. The reason for cancer in the Rif nowadays, even after almost a century has passed since the bombardment, is that genetics [sic] are corrupted. ${ }^{3}$ And more, there is still Arrazi in Nador. Arazzi is the fabric in which the Spanish Army loaded gas barrels during the colonial period and it's the first place conquered by the army of Franco before he started the war in Spain. Nowadays, the fabric has been transformed into something else: nobody knows how many tons of gas were loaded there, but it must have been dropped, concealed both under hills and orchards and under the sea, as well as under the streets. There are places in the Rif in which it doesn't grow anything, anymore. Deserts, and we have a rich biome! The land is still poisoned.

(Mr. Raha, Rabat, 3 May 2017)

If the claims of an epidemic made by the Hirak were completely unmatched by epidemiological or historical data, since studies about the topic in the region where non-existent, at the same time also the construction of the oncological centre in Al Hoceima also appeared to be unjustified. With the oncological centre having been constructed during a phase of political discussion with Spain about the presence of two Spanish enclaves (Ceuta and Melilla) on Moroccan soil and the expropriation of Saharawi land in Western Sahara, this daily hospital turned out to be of great political relevance for the relationship between the two countries. It was also an example of how political capital trumped healthcare: the silence about the Rif's history of cancer and the silence about the state's responsibility for the neglect of the region was the price that was paid for a strong political relationship. In a surprisingly concise and revelatory final interview with the local ministerial delegate of Al Hoceima at the end of my fieldwork, I was 'gifted' the following sentence, which was so simple but so revealing and direct: 'The CRO [Centre Regional d'Oncologie] was built for political reasons' (Mr. Ben Ali, Al Hoceima, 1 September 2017).

\section{Interlude: Silence, Voices, Narratives}

My above-mentioned encounter with the Health Minister's secretary is a perfect example of how the difficulty and frustration that I had when came to interviewing and having productive dialogues with health professionals and hospital directors in Rabat and Casablanca and the Health Minister's bureaucrats and representatives: the institutional silence on the use of mustard gas was, clearly in my view, rationally implied by the administrative neglect of the needs of the Rif's human population; by the absence of data that made the Hirak's claims appear to be merely the claims of desperate people plagued by illiteracy, prejudice and ignorance; and by the structure of a poorly functioning centralist sanitary model. This is what led different institutional actors to sustain the argument that the collective voices of subalterns were manipulated by local associations and anchored to populist narratives and to historical revendications that have become mere 'honour' issues. It was in consequence of this 'ethnicist' nature of the discourse that, according to my interlocutors, 
the marginalisation was excessively felt, and the cancer was perceived as more widespread in the Rif than in other regions.

So if on one side the narrative of marginalisation was used by the Hirak movement and the local political associations to stress the isolation of the region and the responsibility of the state to address the situation, on the other side this same rhetoric was used by the political and administrative class to affirm that in virtue of this condition of abandonment Rifans had developed a sort of 'auto-commiseration', a victim mentality, that people were not able to develop any constructive solution other than to protest, and that they were mere complainers.

In this scenario, silence became the carbon paper of power. On one side emerged the subaltern narration of Rifans, formulated on 'circumstantial' knowledge from those that were in search of help: victims of colonial violence, of historical abandonment, of an invisible and unmeasurable land poisoning. On the other part, the peculiar absence of a historical and bureaucratic reconnaissance of the Rif and of an epidemiological tracing of the region, witnessed a conflict between empiric and bureaucratic knowledge, between local and official versions, issues that turned within a void and a silence that were favourable to the maintaining of state control.

At the same time, the Hirak movement was calling attention towards cancer victims and still not a single voice from the patients and sufferers had emerged. The silence that linked the voices of the sufferers and the studies on the cancer epidemic was in exact opposition to all those voices that were mobilised on the Rif's economic and public health situation and the Hirak protest movement.

\section{Stories}

\section{Silence: Living and Dying Morally}

As I obtained a six-week permit to conduct research inside the oncological centre of Al Hoceima, which was reopened by July, I realised that the interpretive lens with which I had dichotomised the parts involved in the 'Hirak affair' were both in the interest of my interlocutors, and inadequate to describe the concrete reality of the everyday life of the patients. In the $\mathrm{CRO}$, silence emerged as a concrete relational practice between sufferers and their parents, as a contract in (medical) staff-patient or staff-kin relations. Here, I found both those silences witnessed by Franz Fanon, for whom 'refusals to present at the medical visit ... are a form of resistance against the mensonge of the colonial [and "post-colonial"] situation' (Beneduce 2012: 19, my emphasis), and silences that were completely other things: solutions to preserve a moral identity, a familiar peace and a sense of psychological, ethical and economic integrity.

Many relatives refused to tell patients the origin of their disease in order to prevent the latter from becoming depressed or from wanting to commit suicide: I remember a man my age, telling me in English that his father was thought to have contracted the generic flu, while another one, while we were in the radiotherapy's room, told me that the cause was surely the gas left after the Spanish War and that in the region dying of cancer was considered the worst possible fate.

On the other side, some sufferers refused to continue therapy or simply to interrupt it, without saying anything about the nature of their illness. They disappeared, dying without anyone knowing the cause. A woman on the medical staff told me that these decisions, which represented one of the major problems for the staff in the centre, came about due to a general sense of economic and social misery, to a feeling that there were no other alternatives and to the stigmatisation of being ill:

Even my mother, who is a cultured and educated woman, refused to reveal the cause of my grandmother's death. Even at the funeral! My grandmother had never told us of being sick. Stigmatisation is common in all North Africa because cancer is caused by a genetic predisposition and by specific events. Everybody fears it, but true believers, those who have faith, know that through God they will be healed. Fatalism is not faith, it is just refusal.

(Mss. Nadia, CRO, 10 August 2017)

In my observations, when patients and their families were both informed of the former's medical situation, the resultant decisions seemed in effect to revolve around the necessity of managing the risk of stigmatisation. This concern, to be sure, is prominent in many oncological contexts (Mc Mullin 2016). Still, silence appears to retain a singular relational value.

I recall a small group of women who would eat, chat and watch videos on their phones together while sitting in the radiotherapy hall. This group became one of my sources for interviews and chats during my days spent in the medical centre. On many occasions, these women revealed a more resigned and critical approach to cancer and life with the disease: when I had the opportunity to talk with them about the mustard gas, Hirak and history, the narrative constructed to explain the political and historical 
role of cancer in the region appeared to be fragile and inaccurate from their point of view. These women were far more concerned with the medical practices of the centre and rejected the interpretations of the narrative as excessively abstract. I noticed that, in comparison to those patients for whom family was more present, they generally tried hard to build good relations with the medical staff. At the same time, they tried to hide their disease in public, avoiding all possible contact with staff members outside the centre. In contrast, many old men, for example, were glad to talk with me both inside and outside the building and to share in my presence their situation with their friends so as to legitimise a condition that, in other cases and under other circumstances, would have never been shared.

This group of women told me the importance of not reading 'silence practices' as mere acts of desperation, only as practices of last resort. For those who managed to construct a solid relational group, being silent carried the meaning of a relatively free condition to move inside and outside the centre, going into the main square of $\mathrm{Al}$ Hoceima to enjoy summer music, to see youngsters playing or to chat about their current situation, daily issues or future prospects.

Bounya, a young marketer of the local suq ('market'), expressed in another way the need to not interpret exclusively in critical terms the practice of silence. He lost his father to cancer when he was young:

Here we are speaking about ghnana, shame. But my father wasn't ashamed. He kept silence around his disease for us: here everybody knows that of cancer you can die, cures cost too much, you must move away from your work and your house to be cured. But this is not relevant. People like my father want to leave to us a future, without preoccupation, without the disease. We know from our parents the history of the Rif, we know what is here and who we are.

(Bounya, Al Hoceima, 14 August 2017)

\section{Words: For a Hermeneutic of History}

While in the public debate silence emerged as a trace of repressive erasure, inside the $\mathrm{CRO}$ the polyhedric value of silence lies in the different ways one can preserve their moral, economic and social networks. Aside from retaining a binary meaning, silence seems here to be close to the 'ways of forgetting' discussed by Paul Connerton (2011) both in the sense of forgetting as 'humiliated silence', as an act to hide one's own condition and to preserve a coherent cultural image, and in the sense of an 'annulment' in that si- lencing one's own sickness represents a way to interrupt the genealogical transmission of a dramatic fate.

Differently from these acts though, silence in the Rif cannot be considered as an epitome of forgetting, as it always addresses a historical and ethical issue. In its plurality, silence mirrors the debate on the usages of memory (Le Goff 1986; Nora 1997; Ricoeur 2000) and the contradictions between truth and acknowledgement inside the institutional setting of transitional justice (Hayner 2001; Nuttall and Coetzee 1998; Soyinka 1999), where

truth commissions aim at the restoration, or creation, of a modern consciousness of time, thereby confirming a characteristically modernist disjuncture between past and present; in turn, this idea of time is profoundly challenged by 'memories of offence' which refuse to let the past go, and which insist that the past habitually 'haunts' the present.

(Bevernage 2010: 116)

More importantly, different positionings in respect of silence seem to pertain to the same narratological horizon while underlining nonetheless different stances towards and 'experiences of history' (Koselleck 1985), in the sense that "memories of offence" can [. . .] recast conceptions of time so that time itself is no longer conceptualized as a "medium of change", and time's passing no longer secures a 'distance' between past and present' (Gumbrecht 2006: 323). This experience of a durational time, while largely unsolved from my fieldwork, can nonetheless be grasped in the dissemination of idioms related to the interconnection of cancer, violence and territory, which refers to the ghostly or uncanny nature of the past while underscoring a widespread feeling of an uncomfortable 'present'. If Mr. Raha spoke about the connection between cancer and the Arazzi, the phantom fabric used to produce and store gas tanks during the Spanish Protectorate, in its protests the Hirak movement was instead often connecting cancer with the word hogra ('contempt').

Coming from the Arabic root عار, which translates both the idea of shame and the idea of disgrace, the term became used in the context of the Algerian Black Spring (2001-2002), translating a lived condition of humiliation or frustration that is structurally produced from power; it is not simply derived from politico-economic and social inequalities conceived as 'structural violence', but it is also actively and intentionally produced: it points towards the abuses of authority, the arbitrariness of institutions and the legitimacy that violence has when it comes from state agents. In $\mathrm{Al}$ Hoceima, the marginalisation, the ab- 
sence of work, the social injustice, and the public health menace that is cancer, all of these were considered as hogra. It is a stigmatisation that affects all societal levels: the stigma of women affected by cancer, who are suspected to have had extra-conjugal relations while their husbands were abroad; the stigma experienced from the Rifans, left aside and militarily repressed during the pan-Arabic period, and sociologically and anthropologically constructed as subjects moved by a natural antipathy for state's administration and impositions.

If the cancer pathology was a trace of hogra, it may be significant to point out that the most known Arabic noun for cancer, moerd el khayb, which means literally the 'uncurable disease' and the 'unspeakable dread', is often translated in the Rif with the word akhanzir, which is related to the Arabic root خنزير, (that can signify both 'pork', 'dirty' and 'forbidden'): the word indicates a peculiar disease of the skin that was diffused in the region during the second quarter of the twentieth century, which many of my interviewees related to the usage of yprite. If the first word is rarely spoken out loud, since (as it came out during my interview in the CRO) it seems to retain a sort of evocative power, the word akhanzir points towards a condemnation of cancer as something impure and at the same time points to its existence as a historical heritage.

All these words, taken as a whole, address a peculiar hermeneutic of history, where cancer, violence and land became the elements of a fatalistic conceptualisation of power relations. Beyond my recounting lie other perspectives: the silence of patients and their relatives, the refusal to conduct interviews or the request to not report the dialogue, the rejection of ghnana (the individual shame of which Bounya spoke) and the silence maintained by the group of women. All these attitudes delineate personal trajectories, different struggles and strategies, and plural and complex stances towards an event and a past that cannot be reduced to univocal interpretations.

While pointing towards silence has helped me in connecting all the fragmented pieces of an unspoken history, the usage of this very same concept mirrors my partial inability to explore further these singular perspectives. Respecting the request made by the group of women to not be included in the research and reporting the only phrase of Bounya that I was able to catch in the few moments of our conversation became for me the primary way of giving space to these unrepresented voices.

In the context of my experience at the $\mathrm{CRO}$, I felt my role as an anthropologist oscillating between the expectations and desires of patients, who searched for a voice with which to criticise their state, and the more than eloquent silences that asked me to unveil the false pretense of doing 'research for research's sake' and to take part in the struggle. Between these steps, the distanced practice of a 'participant observation' became more similar to an 'observed participation' of life and its pain.

\section{Conclusion}

As I felt lost inside bureaucratic labyrinths and intimacies that demanded to be excluded from research, I initially approached the connections between social revendications, infrastructural abandonment, history and repressions in the Rif in the light of the paradigm of structural violence (Farmer 1992). But if undoubtedly this helped me to shed light on a diachronic constant in the relationship between the Moroccan Kingdom and the Rifan region, at the end of my experience I returned home with more doubts and confused feelings than I had at the start of my research.

On the one hand, discourses on structural violence seemed to be well known and handled in the Rifan context, where they appeared continuously in political, social and media encounters between administrations, protesters, associations and researchers. As I went to the field, I was directed to precise contacts and asked to talk about precise things to address the topic of inequalities. In this sense, silence was undoubtedly the 'currency of power' (Achino-Loeb 2006), marking consequently my fieldwork as part of a wider political process of unveiling, with its consequent responsibility to remember and revendicate memory. On the other hand, these same discourses, while helpful in highlighting historical and political obscure zones (and in mobilising people to take charge of the situation), resulted in obscuring other perspectives: those of inhabitants that were struggling to keep their relational network and kin safe from the 'total' impact of cancer; they were entangled in other logics, other problems, other necessities. The latter, while represented as the main victims of historical and political persecutions, were left without singular voices and were only 'talked by'. My presence too, even if sometimes welcomed in a friendly way or even asked for, was still perceived in some cases as a disturbing and uncomfortable risk through which one could 'be talked by'.

Confronting the previous embracing narrative with all these shattered and singular experiences made me reflect on my critical formation and on the 
assertive use that I was making of well-established social readings. Contemporarily, the double struggle of the Hirak and the CRO's patients translated to another contradictory situation. If the great narrative of structural violence, embodied in the epistemic production of Berbers in colonial crimes and political violence perpetrated during the second half of twentieth century, required me to take a position on the right to remember the historical fate of the region, other interlocutors presented instead a different vision, where the remembrance had to go together with the right to move forward, as in the case of Bounya's father.

In this context of epistemic loss, I started to reflect on the pervasive role of silence as a peculiar object that crossed my fieldwork: it was able both to describe my sense of disorientation towards anthropological theories and to provide a way to address a plurality of perspectives located in the wake of a peculiar hermeneutic of history. The connection between cancer, fate, silence, the Rif and its history, which emerged constantly during interviews, told in fact of a particular epistemic space: at the intersection between political history and social memory, between silenced archival and 'circumstantial' knowledge, between state and domestic epidemiologies, silence and cancer emerged as particular ways to address history with its sorrows and responsibilities. If, in the Hirak's narrative, cancer was the trace of a forgotten and haunting past, calling for a break with the national silence, in the ordinary lives of patients and their families in the CRO silence became the way to confront the disease and a tool that helped to transmute pain into responsibility and death into ethical teaching. This duality was well represented in the different and plural uses of silence in the local dialect, which in turn reflected different stances towards a diffused interpretation and vision of history. Silence and cancer became in the end traces of a history and society that 'could not speak' and elements of a relational field that, in its drastic aspects, radiated nonetheless historical responsibility, collective identity and political duty. The memory of losses and a perceived common fate made of poison and harshness that tie together a people and their land became then another aspect of a complex world that I have only partially managed to portray.

Federico Reginato is a PhD Candidate in Social and Political Change at the University of Turin. His research interests cross anthropology, historical sociology and political theory. He is currently working on the relationships between informal economy, territory and government in Morocco.

E-mail: reginato.federico@gmail.com

\section{Notes}

1. The Rif is a Moroccan mountain chain that runs parallel to Mediterranean coast approximately from the Strait of Gibraltar up to the Moulouya River near the Algerian border. It is famous for being the homeland of Berber populations, the epicentre of hashish production, and the site of anthropological fieldwork for studies on segmentary lineage (Gellner 1969).

2. All the names have been modified to preserve the privacy of my interlocutors.

3. While talking to me, Mr. Raha was sorting out piles of files, maps, articles and documents. Here and there, he dug out some papers containing statistics and diagrams about child cancer and the percentages attesting to a prevalence of northern (the Moroccan area in which the Rif is situated) patients in oncological hospitals. However, these papers (as well as the government ones) lack any clear sources and references. Similarly, the existence of Arrazi and the idea of a genomic corruption are also undemonstrated. This last idea was based on the logic that, since yprite has been dumped after the war to conceal its usage, then it must have contaminated both land and sea. I develop further in the last sections the existing linkages between cancer, fate and history that may account for this idea of the genetic transmission of toxicity.

\section{References}

Achino-Loeb, M. L. (2006), Silence: The Currency of Power (New York: Berghahn Books).

Ayache, G. (1981), Les origines de la guerre du Rif [The origins of the Rif's war] (Rabat: Société Marocaine des éditeurs reunì).

Balfour, S. (2002), Deadly Embrace: Morocco and the Road to Spanish Civil War (Oxford: Oxford University Press).

Beneduce, R. (2012), Archeologie del Trauma: Un'antropologia del sottosuolo [Archeology of trauma: An anthropology of the underground] (Rome: Laterza).

Bevernage, B. (2010), 'Writing the Past Out of the Present: History and Politics of Time in Transitional Justice', History Workshop Journal 69, no. 1: 111-131, doi:10.1093/hwj/dbq008. 
Biehl, J., B. Good and A. Kleinman (2007), Subjectivity: Ethnographic Investigations (Oakland: University of California Press).

Collier, S. J., and A. Ong (2005), 'Global Assemblages, Anthropological Problems', in Global Assemblages: Technology, Politics, and Ethics as Anthropological Problems, S. J. Collier and A. Ong (Malden, MA: Blackwell), 3-21.

Connerton, P. (2011), The Spirit of Mourning: History, Memory and the Body (Cambridge: Cambridge University Press).

De Certeau, M. [1975] (2006), La scrittura della storia [The writing of history] (Milan: Jaca Book).

Farmer, P. (1992), AIDS and Accusation: Haiti and the Geography of Blame (Berkeley: University of California Press).

Gellner, E. (1969), Saint of the Atlas (London: Weidenfeld and Nicolson).

Gellner, E., and C. Micaud (1972), Arabs and Berbers: From Tribe to Nation in North Africa (London: Duckworth).

Ginzburg, C. (1986), Miti emblemi spie. Morfologia e storia (Turin: Einaudi)

Good, B. (2012), "Theorizing the "Subject" of Medical and Psychiatric Anthropology', Journal of the Royal Anthropological Institute 18, no. 3: 515-535, doi:10.1111/j.1467-9655.2012.01774.x.

Gramsci, A. (1977), Quaderni del carcere: Quaderni 12-29 [Prison notebooks (Turin: Einaudi).

Gumbrecht, H. U. (2006), 'Presence Achieved in Language', History and Theory 45, no. 3: 317-327, doi:10.1111/j.1468-2303.2006.00367.x.

Hayner, P. (2001), Unspeakable Truths: Confronting State Terror and Atrocity (New York: Routledge).
HCP (Haut Commissariat au Plan, Moroccan Kingdom) (2014), 'Démographie Maroc', http://rgphent ableaux.hcp.ma/Default1/ (accessed 5 May 2019).

Koselleck, R. (1985), Futures Past: On the Semantics of Historical Time, (trans.) K. Tribe (New York: Columbia University Press).

Le Goff, J. L. (1986), Storia e memoria [History and memory] (Turin: Einaudi).

McMullin J. (2016), 'Cancer'. Annual Review of Anthropology 45:251-66.

Montagne, R. [1954] (1973), The Berbers: Their Social and Political Organisation (London: Frank Cass).

Nahass, B. (2014), 'La Mémoire et ses usages: le cas du Rif' [Memory and its uses: The case of the Rif] (PhD diss., Université Hassan II).

Nora, P. (1997), 'Entre mémoire et histoire', in Les lieux de mémoire (Paris: Gallimard), 19-40.

Nuttall, S., and C. Coetzee (eds) (1998), Negotiating the Past: The Making of Memory in South Africa Cape Town (Oxford: Oxford University Press).

Rachik, H. (1990), Sacré et sacrifice dans le Haut Atlas marocain [The sacred and sacrifice in the Moroccan High Atlas] (Casablanca: Afrique Orient).

Ricoeur, P. (2000), La Mémoire, l'histoire, l'oublì [Memory, history, forgetting] (Paris: Seuil).

Smith, L. T. (1999), Decolonizing Methodologies: Research and Indigenous Peoples (New York: Zed Books).

Soyinka, W. (1999), The Burden of Memory, the Muse of Forgiveness (New York: Oxford University Press).

Spivak, G. C. (1988), 'Can the Subaltern Speak?' in Marxism and the Interpretation of Culture, ed. C. Nelson and L. Grossberg (London: Macmillan), 271-315. 